\title{
Wars and Conflicts are Only Randomly Connected with Religion and Religious Beliefs. An Outline of Historical, Cognitive, and Evolutionary Approach
}

\author{
Konrad Szocik \\ University of Information Technology \\ and Management in Rzeszow, \\ Poland
}

e-mail: kszocik@wsiz.rzeszow.pl

\begin{abstract}
:
Many scholars that study of religion and religious beliefs find that they affect behavioral patterns. Some of them suggest that this impact is morally wrong because religion and religious beliefs can cause aggression, conflicts, and wars. However, it seems that this topic is more complicated and complex. Here I show that religion and religious beliefs can affect mentioned above morally wrong patterns only in some particular cases. Usually they do not do it. Here I show an outline of philosophical historical approach that was critically oriented against religion and that accused it about conflicts and wars. Then I briefly discuss two current scientific research approaches to the study of religion, cognitive and evolutionary. They falsify these critically oriented philosophers because they treat connection between religious beliefs and conflicts as random and necessary. The core idea of this paper assumes that religious beliefs do not affect aggression and wars directly. They can sometimes strengthen or weaken some biological mechanisms that then can be used to compete by conflicts or by not-violent inter-group competition.

Keywords: religion, religious beliefs, conflicts, wars, politicization, cognitive science of religion, evolutionary study of religion.
\end{abstract}

\section{Introduction}

Religious beliefs are commonly discussed and studied in the Western world. However, it can be supposed that in the following fifty years they will be the subject matter only of historical studies. Now they are studied not only by historians and philosophers, but also by scientists like cognitive science of religion and evolutionary study of religion scholars. They provide a new insight to almost classical philosophical explanation of connection between religion and religious beliefs, and wars and conflicts. I mean the modern philosophers that since the $16^{\text {th }}$ century have accused religion about leading to aggression and wars. More promising seems to be cognitive and especially evolutionary approach. It is worth bearing in mind psychological approach that usually find more positive than negative results of religious beliefs. Some researchers find that the mediation 
hypothesis suggests that religiosity provides better level of self-control and only in an indirect way can affect socially wrong patterns [24]. Scholars underline positive impact of religious beliefs on reducing criminal behaviors [13]. Other ones point out that the figure of God in the Christian Bible does not affect morally wrong behaviors. All passages that favor these kinds of behaviors were written by the human secondary authors that sometimes rejected God commands [5, p. 20].

Before I discuss the current cognitive and evolutionary explanation of indirect and random connection between religious beliefs and wars, I briefly remind philosophical explanation of this correlation that was one of dominant approaches in the modern times. It can be said that cognitive and evolutionary approaches falsified philosophical explanation that connects religion with conflicts.

\section{The Concept of Religious Tolerance in Poland}

Development of Reformation and protestant denominations since the $16^{\text {th }}$ century has begun the period of so called religious wars and conflicts. There is no doubt that there was some kind of correlations between religious affiliations and various brutal and criminal events that have included small criminal acts and international wars as well. It can be said that the current secularized Western Europe does not have these kinds of conflicts, wars, and smaller criminal acts that were a domain of the period of religious wars and conflicts. There can be found one exemption, terror attacks that usually are prepared by individuals that can use some religious contents. This phenomenon of the current terrorism can lead to belief that an impact of religion on politics or political using of religion has usually wrong consequences. However, the question of terrorism and its religious affiliations is not the issue of this paper (some possible correlations between terrorism and religion are discussed in: [32]). According to the key idea of this paper, association of conflicts with religion and religious beliefs is random and unnecessary coincidence that is the result of using some cultural phenomena. Various cultural phenomena, not only religious can work in similar ways on biologically deeply rooted mechanisms that affect human behavioral patterns. This topic will be discussed later. It can be said that religious contents were only one of the possible phenomena that were particularly used to strengthen and maintain some behaviors, primarily affected by political and social aims.

In this context it seems understandable that the concept of the religious tolerance could not be commonly shared because biological factors that determine dynamics of in-group and intergroup relations were too much rooted in so called human nature. Despite this biological determination, the concept of religious tolerance has emerged in Poland much earlier than in the Western Europe. This concept was a remedy that should provide peaceful coexistence of various religions. This concept has shaped a framework for the Polish legal and political culture, and became the model for the Western Europe.

Paulus Vladimiri (Paweł Włodkowic) prepared the concept of religious agreement and tolerance at the beginning of $15^{\text {th }}$ century and he has presented his ideas in the Council of Constance. He pointed out that nation has the right to self-determination that is independent on its religious affiliation. Vladimiri underlined the power of natural and divine law to reject a legitimacy of religious wars [44, pp. 58-60]. It can be said that his theory has affected the further development of the international law. His approach was implemented in Poland and was one of the most pioneer in the world. In the $16^{\text {th }}$ century Andrzej Frycz Modrzewski claimed that religious tolerance should be the basic principle of the law.

It can be said that these ideas were realized in Poland in the practice of political life. Poland is called "the state without stakes", however there were present protestant denominations like Lutheranism, Calvinism, or Aryanism. In 1645 in Torun (Poland), during the Thirty Years' War $(1618$ - 1648) has been organized Colloquium Charitativum [46, p. 24]. The main purpose of this meeting was to reconcile the Roman Catholic Church and protestant denominations. It can be said that Poland was one of the exemptions in which the state power was found on multicultural social structure and religious tolerance, not on national or religious unity, like in some Western countries. 
Consequently, the Polish case presents that relation between religion and war is not inevitable, like many philosophers have suggested since the $16^{\text {th }}$ and $17^{\text {th }}$ centuries, and later [34]. It is worth to looking for new conditions and particular environment that should work to connect religion and religious beliefs with conflicts and wars. It is possible to find such conditions in Poland in the mid$17^{\text {th }}$ century. I mean the concept of implementation of political unity that was based on the concept of religious unity. This cultural policy was affected by wars with other countries, like Sweden or Russia. It can be said that this period has begun the process of political instrumentalization of religion. Religion and religious beliefs were used as tools that enable differentiation and recognition of the members of one group from other competitive groups.

\section{Emancipation of Philosophy and the Fighting Against Religion}

Philosophers in the Western Europe have tried to emancipate. Their main opponents were political authority and religious institutions. The apogee of this emancipation is the philosophy of the Enlightenment that is focused on the critique of the current politics and religion. Religious wars, beside authoritarian regime, were one of the most meaning sources of Enlightenment philosophy. Uriel da Costa [6] and Baruch Spinoza [29] pointed out that religion and religious beliefs are morally harmful, and that they can affect conflicts. Consequently, Spinoza suggested that politics and ethics should be separated from theology and religion.

Similar thoughts were shared by Pierre Bayle who ran away from France from persecution of Huguenots. The Western philosophers found the links between religion and war that rather were not found by thinkers who have lived in Poland. Texts that have been published in the Western Europe since the $17^{\text {th }}$ century found an insufficiency of religious ethics that should or have to be replaced by natural (philosophical) morality. It seems that these ideas were affected by two factors: religious wars, and mentioned above emancipatory attempts of philosophers who have proposed their tools - reason and reflection - as candidates for new rulers of the world instead of religious superstitions and political power. The frameworks of the new concept of secular morality can be found in Spinoza's Tractatus theologico - politicus (1670) or John Locke' Epistola de tolerantia (1689) [19]. It is worth to bearing in mind an anonymous (however, anonymous only in that time) manuscript entitled The Treatise of the Three Impostors [40]. The title impostors are Moses, Jesus, and Mahomet that are accused by the authors of this manuscript that they have invented religions to achieve their political aims. The French Enlightenment has used these texts in the $18^{\text {th }}$ century to fight with religious superstitions [34].

\section{Radical Critique of Religion in the Philosophy of the Enlightenment}

Some of the Western philosophers have found some events that have confirmed their thesis about political and economic instrumentalization of religion. They have underlined especially the meaning of the Saint Bartholomews' Day massacre (1572) and the revocation of the Edict of Nantes (1685). Voltaire [48] and Denis Diderot [7] had in mind these events when they have considered religion as a system which is used to justify war. Religion has been interpreted as a tool that is used to manipulate society and to maintain violence in order to achieve economical and political aims. Claude Adrien Helvétius has suggested that the global peace requires removal of religion [12, $\mathrm{p}$. 268]. Voltaire published in 1762 Testament of Jean Meslier who was the parson of Etrépigny and one of the first atheists explicite in the European philosophy. Meslier pointed out a strict connection between religion and war. In his opinion, the main cause of negative impact of religion is the concept of an abstract God who is the source of values that work independently on human being. The concept of confession is responsible for transition of moral responsibility from human beings to the concept of God [20, pp. 247-248].

Similar critique of religion can be found in the German philosophy. Georg Wilhelm Friedrich Hegel pointed out that religious wars were affected by „historical faith” that means that moral role is played by religious institutions, not by "moral faith" [11, pp. 171-172]. He noted that 
propagation of religions is a dangerous process for the state [10, p. 255]. It seems that Hegel's critical approach to the moral nature of religion has been developed by Karl Marx's concept of religions as "opium of the people". It is worth bearing in mind that the critical philosophy of religion of Marx was more reliable than earlier, especially enlightenment theories. I mean the concept of alienation. According to Marx, there are various sources and various kinds of alienation, and religiously motivated alienation is only one of them. This approach is very similar to the current evolutionary study of religion (it will be explained later). In this context it can be said that the critique of religion that was appropriate for philosophy of the $17^{\text {th }}$ and $18^{\text {th }}$ centuries was affected not only by the defense of the reason but also by above-mentioned emancipatory attempts.

\section{Religion and Politics}

The Enlightenment-like critique of religion can be met also today. It is alive especially in the context of the current public policies that are developed by religious institutions. Giovanni Simonelli points out that religion was invented to justify violence and to intimidate opponents [27, pp. 14-15]. He recalls the main mentioned above ideas that were proclaimed by some Enlightenment philosophers. Critically oriented philosophers usually refer to the same historical examples like crusades, persecution of Anabaptists, or the slave trade [3, pp. 123-125]. Some of them find that crusades were affected by the papal bulls and priests' exhortations that have sanctified violence by the concept of God and "holy war" identity [43, pp. 126-128]. Political opponents were sometimes presented as enemies of religion. One of the most popular concepts was the concept of the God support for a given policy [28, p. 108].

Similar mechanisms can be found in some terroristic acts that are prepared in the name of Jihad [30, p. 10]. Their protagonists can justify violence and wars by regard to the God's will in similar way like wars and conflicts that were religiously justified in Judaism and Christianity [4, pp. 33-35]. Some parts of Koran are sometimes used to justification of religious wars and aggression. Some individuals and groups refer to these parts that indicate on using of violence against nonbelievers, depreciate them, and promise reward and victory in a war [31, 9:25-29, p. 66]. Islam has played an important role to provide the sense of identity and to provide a divine support for political activity that was used to propagate or to defend Islamic civilization [30]. All monotheistic religions have played similar role in the field of their politicization. Some part of The New Testament can also provide a divine justification for war: "Think not that I am come to send peace on earth: I came not to send peace, but a sword" [42, 10: 34].

The risk of socially harmful kinds of interpretation of the religious texts in the Roman Catholic Church has been stopped by the Second Vatican Council. Before him there were some stigmatized groups like Jews or Protestants [38]. The concept of religious tolerance (we should tolerate other "false" religions) was replaced by the concept of religious freedom (there are not true and false religions or all religions are true or they contains elements of the one truth) during the Council in 1965. This approach has removed the theoretical framework for aggression and the concept of ideological advantage of one religion over another one. The Roman Catholic Church during the Council has rejected thomistic and neo-thomistic philosophy in some fields that are associated with his cultural policy. Saint Thomas Aquinas who was announced by Leo XIII as the main philosopher of the Church [18, pp. 31-33], pointed out that there can occur so called just wars that are morally right. The clergy can provide his support for wars [26, Quest. 40, Art. 2]. The case of thomistic philosophy whose social part was partially rejected during the last Council presents that religious approach toward the war and conflict is strongly context-dependent. It can be used as an argument for mentioned above politicization of religion.

\section{Secularization, Emancipation of Philosophy, and Limited Impact of Religion}

Religious wars and conflicts in the modern times have affected philosophers to looking for a new philosophical base for morality that could avoid religious conflicts [9, p. 22]. It seems that an 
emergence and propagation of the British deism expresses this attempt. The idea to separate ethics and morality from theology and religion has affected development of the critical Western philosophy. One of his main tools was a belief that religion is connected with war. Religious wars and conflicts showed that religion cannot support morality.

Immanuel Kant like Hegel [11, pp. 171-172] pointed out that religion is used to present human duties as the God commands [15, p. 203]. Kant has rejected two years before Hegelian Positivität der christlichen Religion the concept of moral justification by participation in institutional rites. He interpreted rites and sacraments as some kind of fetishization of religion that destroys individual moral patterns [15]. The concept of a difference between moral and historical faith is a common point of view that was commonly shared by Hegel and Søren Kierkegaard. Kant, Hegel, and also Kierkegaard have suggested that institutional nature of religion and fetishization of faith can lead to war and violence that can be justified by the concept of God's will. Kantian and Hegelian philosophy of religion assumes that religion is an inner morality that respects rule of love of neighbor and does not require institution to work.

Critical philosophy or religion that has been developed since the $16^{\text {th }}$ century has affected political solutions in the Western Europe. The impact of religion was limited to the current role as one of the many agents in the democratic public sphere. The Second Vatican Council in some sense has accepted this critical approach to the social and political role that can be played by religion. The new Church approach interprets religion in Kantian and Hegelian sense like the source for individual morality that is based on the concept of the dignity of the human being [38]. The Church accepted political secularization in Europe [16]. The idea of secularization of religion refers to the concept of privatization of religion that prohibits an impact of religion on the public legislation, and discusses morally wrong nature of religious patterns [17, pp. V-VII]. However, the legislation of the European Union that proclaims secularization and privatization of religion does not suggest a harmful nature of religion. A starting point is a factual religious and cultural pluralism that excludes norms that are connected with particular religion and cannot be commonly shared. Consequently, the concept of separation or independence of law and morality is probably an optimal solution within pluralistic societies [36].

\section{The Current Scientific Approaches to the Study of Religion}

Philosophy until the $19^{\text {th }}$ century has provided probably unique theoretical framework for the study of religion. Beside two dominant approaches in the $20^{\text {th }}$ centuries, psychology and sociology of religion, there are two current scientific approaches to the study of religion, cognitive science of religion (CSR) and evolutionary study of religion (ESR). They provide a new explanation of possible correlation between religion and wars that is different than mentioned above philosophical explanation. The starting point of these two approaches is so called human nature that is the source of various, sometimes right and sometimes wrong, behavioral patterns. Religion and religious beliefs do not play such important role in this field like many philosophers have assumed before. It can be said that in the light of CSR and ESR mentioned above philosophers have overestimated a negative impact of religion. The same can be said about these philosophers who have defended religion and underlined that religion is a source of morality. It seems that both philosophical approaches are incorrect.

\section{Cognitive Approach or Why We Do Not Kill and Die for Mickey Mouse}

CSR points out that religion and religious beliefs are by-products of human cognition [2]. The core idea states that cognition contains some mechanisms and modules that have evolved in the Pleistocene for evolutionarily purposes that are strictly connected with survival and reproduction. However, the nature of these mechanisms prefers religious/supernatural contents. One of them is agency detection module that should looks for predator and prey in environment [39]. According to CSR scholars, this module is hyperactive and has a tendency to find biologically non-existing 
entities like religious ones. Other cognitive modules that favor religious beliefs are anthropomorphic explanation of the world, design stance, looking for purpose, or Theory of Mind. To sum, CSR assumes that the nature and structure of cognition makes religious contents more natural than other kinds of beliefs [41]. CSR explains in this way a cross-culture presence of the same or very similar religious contents.

If cognition favors religious beliefs, behavioral patterns that are affected by these beliefs express human instincts and intuitions that were evolved in the past environment. It seems that at the base of CSR it is easier to explain positive rather than negative impact of religion and religious beliefs. CSR states that religious figures can have positive impact on behaviors because they have privileged access to strategically important information about believers. This concept is associated with another one that states that "watched people are nice people". It is one of the eight rules of "Big Gods" that have been proposed by Ara Norenzayan. The following other ones also underline positive behavioral impact of religions that includes so called Big Gods: "2. Religion is more in the situation than in the person; 3. Hell is stronger than heaven; 4. Trust people who trust in God; 5. Religious actions speak louder than words; 6. Unworshipped gods are impotent gods; 7. Big gods for big groups; 8. Religious groups cooperate in order to compete" [21].

Other cognitive approaches underline positive nature of the concept of an afterlife, or cohesive nature of doctrinal and imagistic kinds of rituals. Jonathan Jong and Jamin Halberstadt explain an impact of the death anxiety for origin and acquisition of religious beliefs [14]. Like Scott Atran notes, Mickey Mouse cannot provoke anyone to die for the idea that Mickey Mouse really exists. However, religious people can die for their beliefs [1]. People do not believe that Mickey Mouse, Batman, or Santa Clause have privileged access to their thought like, for instance, Jesus Christ. Atran, one of the founders and the leading world experts in the study of religion explains also, using among others CSR, axiological and religious roots of the current suicidal terrorism. His research shows that religious beliefs can affect behavioral patterns both in right and wrong ways. However, it is worth to bearing in mind the concept of parochial altruism that assumes that people are better at in-group than at out-group levels [25]. In this context it can be said that people behave according to some biological mechanisms (later in this paper) that are context-dependent because they can be strengthened or weakened by cultural phenomena like religious or political concepts. This issue refers to ESR.

\section{Evolutionary Approach and Religion, and Religious Beliefs as an Adaptation}

The key idea of ESR differs from CSR. ESR points out that religion and religious beliefs are adaptation or have adaptadness. ESR scholars usually reject CSR approach that explains religious beliefs like by-products of cognition. Religious beliefs and some parts of religion could be the object of selective pressure of biological evolution. It is possible to define if a given religious feature can be adaptation that is the product of natural selection. There are some features that adaptation should contain [45]. There is no doubt that religious elements can be interpreted as adaptations or something that have adaptadness because they can increase chances for survival and reproduction. Some scholars find that some religious beliefs and other parts of religion or religious systems at least in some periods and populations can work as adaptations [37]. David Sloan Wilson explains in evolutionary terms of survival and reproduction five religions like Judaism, the Early Christianity, Calvinism, the Bali water temple system, and the Korean Christian Church in the United States [47]. All of them were used to increase in-group cohesion and solidarity and, consequently, they have strengthened chances for survival. Religious beliefs usually have good impact on health, increase the level of reproduction, and they can motivate believers to self-sacrifice for the group welfare (Mickey Mouse or Batman usually cannot).

How is possible to explain correlation between religion, religious beliefs, and conflicts in this evolutionary framework? Like CSR, ESR does not suggest that religious contents lead to wars and conflicts. The main idea is an assumption that religious beliefs can work as adaptations. Consequently, if they are adaptations or have adaptive nature, they can support various kinds of 
behavioral patterns. These patterns sometimes lead to wars and aggression, and sometimes do not. It can be said that they work at biological mechanisms like kin selection, direct and indirect reciprocity, or group selection. Religious beliefs can provide prosocial patterns, however it seems that this function is random and not obvious [23]. Some scholars find that religious contents are not sufficient and necessary cultural tools to provide cooperation and they have to co-work with other cultural phenomena [22]. Inter-group conflicts and wars can be selectively advantageous if they can provide new territory, water and food resources, and mates. If religious beliefs strengthen in-group cohesion and cooperation, they can provide an advantage for a given group over a competitive one. In this sense it can be said that religious beliefs can provide solutions like mentioned cohesion, solidarity, or self-sacrifice that then can work during inter-group competition. These competitions often work as conflicts and wars. However, religious systems are not unique cultural tool that can do it. Similar work is maintained by other phenomena like political, legal, or other traditional cultural phenomena. It seems that a specific feature of religion and religious beliefs is associated with the mentioned above nature of religious figures like a privileged access to thoughts of believers.

\section{Religion as In-group Marker for a Breeding Population}

It can be assumed that connection between religious contents and conflicts is only random and not necessary. Religious beliefs do not affect directly aggression and wars. As I mentioned earlier, they can strengthen or weaken biological mechanisms that cause selfishness and conflicts or altruism and cooperation. This function can be described as being in-group marker for a breeding population. Jay Feierman presents this approach and he points out that religious contents do it to enabling mutual recognition of the in-group members [8, p. 62]. It can be assumed that a given in-group will fight with other competitive groups with or without religious beliefs.

Beliefs are signals that provide cohesion and distinctive signs. This role is played by very irrational and useless beliefs. I mean some of the Roman Catholic statements like the concept of the Blessed Virgin Mary - the Mother of Jesus or the concept of the Jesus Resurrection. They are pragmatically useless because they do not affect any kinds of behavioral patterns. If someone believes that Jesus resurrected what kinds of behaviors this statement can provoke? It can lead to morally right (self-sacrifice, altruism, like in the case of the Early Christianity and of all heroically merciful Christians in the entire world) and wrong acts (like during the mentioned above religious wars in the Western Europe or in the case of anti-Semitism). However, the concept of Jesus Resurrection does not lead directly to any kinds of mentioned behaviors. A given group decides which patterns will be favored in the current time because particular environmental conditions shape the nature of adaptations. In the period of the Early Christianity practical mercy and charity were adaptive. For institutional kinds of Christianity more adaptive can be other kinds of behaviors. Other patterns are adaptive for the clergy and for the laity. However, the main idea is as follows: that does not matter what patterns will be affected by particular beliefs. Beliefs have to differentiate one group from another one. In the mentioned example, one population is marked by the concept of Jesus Resurrection. Other competitive groups do not share this concept and they can have other irrational and pragmatically useless beliefs.

To conclude, ESR in general does not assume that religious beliefs provoke aggression and conflicts. These events are rather by-products of religiously motivated or strengthened cohesion and solidarity. Of course, some fragments of the sacred texts can contain some phrases that can affect aggression and criminal acts. However, these fragments can work today as old adaptations that could be used in the past when these texts were written, but that are not adaptive today. It can be said that some religious beliefs can affect directly wrong acts when a given population will tend to expansion and domination and if it needs supportive ideas. The concept of an afterlife can affect eusociality that then can favor altruism toward others or conflicts with non-believers. 


\section{Conclusion}

The main idea of this paper is an outline of some approaches that were developed toward the issue of connection between religion and war. Critically oriented European philosophers since the $16^{\text {th }}$ century often pointed out that religion and religious beliefs can affect aggression, conflicts and wars. Some of them suggested that religious contents have morally wrong nature. Other ones tried to defend natural religion but they accused institutional kinds of religion. Consequently, religion and religious beliefs usually were interpreted by European philosophers as phenomena that in negative way affect so called human nature.

This philosophical critique was effective for their protagonists because religion lost his dominant social and political position. However, in the light of the current scientific research approaches to the study of religion it seems that religion and religious beliefs do not cause directly aggression, conflicts, and wars. They can strengthen these patterns when they are used to these purposes. It can be said that the way of using religious beliefs depends on the current level of development of a given population. Some of them need wars and conflicts to develop and they can treat commonly shared religious beliefs as a good tool to provide unity and solidarity or even motivate to self-sacrifice and to "killing and dying for the sake of an idea", like Scott Atran notes. Perhaps this kind of explanation could be applied to the phenomenon of some individuals and groups associated with Islam that can use this religion as a marker that informs about their group affiliation in opposition to other competitive groups that do not share Islam or some kind of interpretation of Islam.

To conclude, perhaps it would be possible to find some correlations between the Polish concept of religious tolerance that has been proposed by Vladimiri, and the current conclusions of CSR and ESR. Vladimir noted that there is no sense to fight by various religious beliefs and affiliations. Religious beliefs are various and various populations have different particular beliefs. However, their main function is in-group marking that can provide cohesion and cooperation. Dependently on the current level of social and political development, a given group can use his ingroup cooperation that sometimes can be strengthened by religious beliefs, to compete with other ones by knowledge and culture, or by aggression and wars.

\section{References}

1. Atran, S. In Gods We Trust: The Evolutionary Landscape of Religion. Oxford University Press: Oxford, 2002.

2. Boyer, P. The Naturalness of Religious Ideas: A Cognitive Theory of Religion. BerkeleyLondon, 1994.

3. Butselaar, van J. The Promise of the Kingdom and the Reality of Sin: Christian Religion, Conflict and Visions for Peace. In. G. ter Haar, J. J. Busuttil (eds.). Bridge or Barrier. Religion, Violence and Visions for Peace. Brill: Leiden, Boston, 2005.

4. Cook, D. Understanding Jihad. University of California Press: Berkeley, 2005.

5. Copan, P., Flannagan, M. Did God really command Genocide? Baker Books: Michigan, 2014.

6. Costa, U. da. Wizerunek wtasny żywota. Transl. K. Dresdner. Państwowy Instytut Wydawniczy: Warszawa, 1960.

7. Diderot, D. Encyklopedia albo słownik rozumowany nauk, sztuk i rzemiost (Wybór). Transl. E. Rzadkowska. Wydawnictwo Zakładu Narodowego imienia Ossolińskich: Wrocław, 1952.

8. Feierman, J. R. How Some Major Components of Religion Could Have Evolved by Natural Selection? In. E. Voland, W. Schiefenhovel (eds.). The biological evolution of religious mind and behavior. Berlin Heidelberg: Springer, 2009.

9. Gawlick, G. Der Deismus im Colloquium Heptaplomeres. In. G. Gawlick, F. Niewőhner (eds.). Jean Bodins Colloquium Heptaplomeres. Harrassowitz: Wiesbaden, 1996.

10. Hegel, G. W. F. Wykłady z filozofii dziejów. V. 2. Transl. J. Grabowski, A. Landman. PWN: Warszawa, 1958. 
11. Hegel, G. W. H. Pozytywność religii chrześcijańskiej. In. G. W. H. Hegel. Pisma wczesne z filozofii religii. Transl. G. Sowinski. Wydawnictwo Znak: Kraków, 1999.

12. Helvétius, C. A. De L'Esprit. V. 1. Amsterdam and Leipzig, Arkstee and Merkus, 1759. https://www.biblegateway.com/passage/? search=Matthew+10\%3A34\&version=KJV

13. Johnson, B. R., Schroeder, C. S. Religion, Crime, and Criminal Justice. Oxford University Press: Oxford, 2014.

14. Jong, J., Halberstadt, J. Death Anxiety and Religious Belief. An Existential Psychology of Religion. Bloomsbury Academic, 2016.

15. Kant, I. Religion within the Boundary of Pure Reason. Transl. J. W. Semple, Thomas Clarke: Edinburgh, 1838.

16. Konstytucja dogmatyczna o Kościele. In. Sobór Watykański II. Konstytucje. Dekrety. Deklaracje. Pallottinum: Poznań,1968.

17. Lecaldano, E. Un etica senza Dio. Laterza: Roma, Bari, 2006.

18. Leon XIII. Aeterni patris. Te Deum: Warszawa, 2003.

19. Locke, J. Epistola de tolerantia. In. J. Locke. Letters concerning Toleration. Printed for A. Millar: London, 1765.

20. Meslier, J. Testament, Le Bon Sens du Curé suivi de son Testament. Palais des Thermes de Julien: Paris, 1802.

21. Norenzayan, A. Big Gods: How Religion Transformed Cooperation and Conflict. Princeton University Press, 2013.

22. Norenzayan, A., Shariff, A. F., Gervais, W. M., Aiyana, K. Willard, R., McNamara, A., Slingerland, E. Henrich, J. The cultural evolution of prosocial religions. Behavioral and brain sciences, 39, 2016.

23. Oviedo, L. Religious attitudes and prosocial behavior: A systematic review of published research. Religion, Brain \& Behavior, Online DOI: 10.1080/2153599X.2014.992803, 2015.

24. Reisig, M. D., Wolfe, S. E., Pratt, T. C. Low Self-Control and the Religiosity-Crime Relationship. Criminal Justice and Behavior, June 4, 2012.

25. Rusch, $\mathrm{H}$. The evolutionary interplay of intergroup conflict and altruism in humans: a review of parochial altruism theory and prospects for its extension. Proc. R. Soc. B, 281, 2014.

26. Saint Thomas. Suma teologiczna. V. 16. Transl. A. Głażewski. Veritas: London, 1967.

27. Simonelli, G. Perche non credo in Dio. La Fiaccola: Ragusa, 1997.

28. Slattery, M. W. Jesus the Warrior?: Historical Christian Perspectives and Problems on the Morality of War and the Waging of Peace. Marquette University Press: Milwaukee, 2007.

29. Spinoza, B. Traktat teologiczno - polityczny. In. B. Spinoza. Dzieła. V. 2. Transl. I. Halpern, Gebethner i Wolff: Warszawa, 1916.

30. Springer, D. R., Regens, J. L., Edger, D. N. Islamic Radicalism and Global Jihad. Georgetown University Press: Washington, 2009.

31. Święty Koran. Transl. M. Taha Żuk, W. Wojciechowski. Londyn, 1990.

32. Szocik, K. An Axiological Aspect of Terrorism: Remarks on Scott Atran's Perspective. Journal of Applied Security Research, 2016, Vol. 11, No. 2, pp. 1-13.

33. Szocik, K. Ateistyczne nurty filozofii Oświecenia. Wpływ skrajnego materializmu i racjonalizmu. Rocznik Wydziału Filozoficznego Akademii Ignatianum, XIX/1, 2013a.

34. Szocik, K. Ateizm filozoficzny. Zarys historii i krytyka neotomistyczna. Zakład Wydawniczy „Nomos”: Kraków 2014a.

35. Szocik, K. Czy uzasadnione jest wiązanie wojny z religią? Studia Polityczne, nr 3 (39) 2015a, pp. 167-181.

36. Szocik, K. Dlaczego potrzebna jest sekularyzacja? Przeglą, Nr 11 (585), 20 March, pp. 50-51, 2011.

37. Szocik, K. Evolutionary approach to the study of religion. Religion and religious beliefs as an adaptation (in review).

38. Szocik, K. Jana Pawła II idee filozoficzne. Między ortodoksja a sekularyzacja. Wydawnictwa Uniwersytetu Warszawskiego: Warszawa 2015b. 
39. Szocik, K. Kognitywna teoria religii a naturalność teizmu i ateizmu. Krytyka założenia o intuicyjnej religijności człowieka. In. J. Woleński, A. Dąbrowski (eds.). Metodologiczne $i$ teoretyczne problemy kognitywistyki. Copernicus Center Press: Kraków, 2014b, pp. 349-387.

40. Szocik, K. Traktat o trzech oszustach: Mojżeszu, Jezusie i Mahomecie jako przykład radykalnej krytyki religii pozytywnych. Przeglad Filozoficzny. Nowa Seria, R. 22: 2013b, Nr 1 (85), pp. 127-135.

41. Szocik, K., Walden, P. Why atheism is more natural than religion. Studia Religiologica, 48 (4), 2015, pp. 313-326.

42. The Gospel of Saint Matthew.

43. Tyerman, Ch. Fighting for Christendom. Holy War and the Crusades. Oxford University Press: Oxford, 2004.

44. Vladimiri, P. (Paweł Włodkowic). Saevientibus. In. L. Ehrlich. Pisma wybrane Pawła Włodkowica. V. 1. Instytut Wydawniczy PAX: Warszawa, 1968.

45. Voland, E., Schiefenhovel, W. (eds.). The biological evolution of religious mind and behavior. Berlin Heidelberg: Springer, 2009.

46. Weintraub, W. Tolerance and Intolerance in Old Poland. Canadian Slavonic Papers, Vol. 13, No. 1, Spring, 1971.

47. Wilson, D. S. Darwin's Cathedral. Evolution, religion, and the nature of society. Chicago London: The University of Chicago Press, 2002.

48. Wolter. Traktat o tolerancji napisany z powodu śmierci Jana Calasa. Transl. Z. Ryłko, A. Sowiński. Państwowy Instytut Wydawniczy: Warszawa, 1956.

\section{Notes}

1. This paper is a continuation of thoughts that were published in the following paper: K. Szocik, Czy uzasadnione jest wiązanie wojny z religia??, Studia Polityczne, nr 3 (39) 2015, pp. 167-181. The current paper contains some modified fragments of that former one in the first, historical philosophical part. 